\title{
How Can Open Inquiry Enhancing Students' Scientific Attitude Through Chemistry Learning?
}

\author{
Betzy Rampean ${ }^{1, *}$ Eli Roheti ${ }^{2}$ Jewish Septriwanto ${ }^{3}$, Meilan Lengkong ${ }^{4}$ \\ 1,2 Master of Education in Chemistry, Graduate School, Universitas Negeri Yogyakarta, Jl. Colombo No. 1 \\ Depok Sleman, DIY 55281, Indonesia \\ ${ }^{3}$ Graduate School of Mathematics Educations, Universitas Negeri Yogyakarta, Indonesia \\ ${ }^{4}$ Educational Research and Evaluation, Graduate School, Universitas Negeri Yogyakarta, Sleman, Indonesia. \\ *Corresponding author. Email: betzyayu.2019@student.uny.ac.id
}

\begin{abstract}
This literature review aimed to analyze the effectiveness of open inquiry learning on students' scientific attitude. Open inquiry learning is a learning model has the most complex level of scientific inquiry that gives students the opportunity to be able to identify errors, submit suggestions, to support or reject according to existing theories, computed chemical data through a mathematical process, and concepts so that students can improve their ability to investigate independently in open inquiry and students are able to carry out supervision and self-correction. The method of this study is a literature reviews were analyzed of the thirty two articles with the keywords which are used in the search are scientific attitude and open inquiry learning with a span of time from 2005 to 2020. This in-depth literature review uses the several steps: selection of the articles, analysis the article studies and categorization. Based on the literature review, students' scientific attitude will enhance through clear instructions which involve students to design the chemistry learning activities. This finding indicated that open inquiry learning activities effective to improve students' scientific attitude.
\end{abstract}

Keywords: Chemistry learning, Open inquiry learning, Scientific attitude.

\section{INTRODUCTION}

Life in the $21^{\text {st }}$ century is growing increasingly complex. This development occurs globally due to the influence of science and technology which are increasingly integrated with human life; involve the political, social, and economic fields known as techno-science [1]. The important thing in creating $21^{\text {st }}$ century abilities is the scientific attitude that contains the values of character education that can maximize students better attending the learning process in class. Scientific attitudes such as curiosity, honesty, cooperation, open-minded, diligent, and thoughtful ideas enable students to explore their initial knowledge and interpret real impression they experience with stimulated questions so that students are stimulated to respond and express their opinions [2]. These activities include part of open scientific attitudes for thoughts and ideas, building their knowledge by working together between teachers and students as well as between students and students to exchange experiences during teaching and learning activities in class [1] - [2].
Moreover, Budiharti and Waras [3] stated that scientific attitude has its own machinery, these dimensions included the dimension of curiosity, data/facts respect, critical thinking, discovery and creativity, open mindedness and cooperation, perseverance and sensitivity of environmental changes so as to upgrade the quality of learning of students. Scientific attitude is an attribute that must be possessed by a scientist to do his work so that scientific attitude is needed by students to notice how theory meets practice [4]. But in reality based on the results of research by Misbah et al [5] that the scientific attitude scores of students in one of the senior high schools in Indonesia are still in the average range of 1.42 from the highest score are 3 . The same thing was disclosed by Ozden \& Yenice [6] that the scientific attitude score of students are still at an average level are 139.7 from the highest score are 200.00 .

Enhancement of scientific attitudes can be carried out by applying an inquiry-based learning model. This is because inquiry-based learning can improve 
creative thinking skills and scientific attitudes through activities in facing with some authentic problems during learning activities by conducting research. This learning process can also be avowed as an effective learning activity related to increase students 'creative thinking skills and an excellent increase in students' scientific attitudes [7]. The same thing was stated by Widowati, Nurohman \& Anjarsari [8] is open inquiry learning can increase students' scientific attitudes in learning science.

\section{RESEARCH METHOD}

This is a literature review from previous research which related to open inquiry learning method in chemistry learning. This literature review includes research on scientific attitude in chemistry learning. To investigate this study, we refer to the previous articles related to the open inquiry learning effectiveness on students' scientific attitude. The following steps were taken to investigate the effectiveness of open inquiry learning method on students' scientific attitude: (1) Selection of the Articles, (2) Analysis of Studies and (3) Categorization of the Articles.

\subsection{Selection of the Articles}

Articles selection for identified science education articles related to open inquiry learning and scientific attitude, started from peer-reviewed research journal in the Google Scholar database. The keywords which are used in the search are 'scientific attitude' and 'inquiry' learning' with a span of time from 2005 to 2020 . In the beginning, the researchers used the Google Scholar website "https://scholar.google.com/" and IOP database website "https://iopscience.iop.org/" total of 17.200 full texts was found. To limit the search of match articles which were appropriate with keywords, only open inquiry learning research articles were selected. The numbers of articles were 140 on Google Scholar and IOP database.

At the second phase screening, the researchers select journals that focus on whence open inquiry learning is effective on students' scientific attitude. As a result, twenty seven articles were identified.

\subsection{Analysis of Studies}

The literature reviews were analyzed of the thirty two articles were selected according to the research question articles have to be analyzed in same term/coding. There are 8 articles that use open
The purpose of discussing open inquiry learning to improve students' scientific attitude through literature review was to investigate the effectiveness of open inquiry learning on students' scientific attitude. The previous studies on open inquiry learning and scientific attitude are varied, and each researcher has different perspective on interpreting and conducting open inquiry learning and scientific attitude. The question guides this study is how is the effectiveness of open inquiry learning on students' scientific attitude?

inquiry learning and 24 articles that explain open inquiry learning is effective on students' scientific attitude in chemistry learning.

\subsection{Categorization of the Articles}

Each article was reviewed in light of the developing set of research questions until the entire set of data was treated. The researchers also ensured that each article had the potential to fit into more than one

finding (and sometimes many more).

\section{RESULTS AND DISCUSSION}

\subsection{What is "Open Inquiry Learning"?}

Inquiry is defined as experience and exploration. Open inquiry involves students in the learning process so as to gain a deeper understanding of the material being taught. Open inquiry is important to ensure that students not only memorize the information needed but also be implemented to the development of their own questions, calculate mathematical data, and understanding [9]. Generally, open inquiry is an active learning process where students answer research questions through data analysis [10].

Koksal \& Barberoglu [11] stated that there are two characteristics of inquiry learning, they are structured and unstructured inquiry. The characteristic of structured inquiry is that students get complete instructions that lead to procedures designed and obtain certain concepts or principles. In this case, students still develop their procedures independently; the task of educators is only to guide. The characteristics of unstructured inquiry are only presentations of problems, and students are free to choose and use their respective procedures, compile data, analyze and then draw conclusions. Inquiry is an instructional technique that line with the principles of constructivism in education. Constructivists assert that people gain knowledge by constructing meaning based on their experience with the environment [12]. 
The inquiry learning model actively implicates students in finding and finding their knowledge whiles the educator as a facilitator and guides the course of learning. In searching and finding answers to a problem students are required to think critically and analytically [13]. In addition, the inquiry learning model helps students to develop intellectual discipline and qualified skills to improve questions and seek answers are hidden from students' curiosity. The inquiry learning phase is divided into five steps: (1) learners are involved in inquiry questions; (2) learners explore answers to questions by planning, designing, the results of the experiment, and recording the results of the experiment; (3) students make an explanation of the experiment data into the answers to questions; (4) students describe, extend, or apply their findings in new contexts; and (5) students evaluate the experiment process and produce various methods [14].

Inquiry has four levels in its implementation as a learning model. The level of each inquiry illustrates the diminishing involvement of the teacher in the activities or all activities of the students, so that the students are given an important position then and responsible for the learning process as the role of scientists both the freedom to express ideas, make decisions and solve problems in learning in their own style or way of thinking. The four levels or levels of inquiry are more detailed in Table 1 [15].

Table 1. Inquiry level

\begin{tabular}{|c|l|l|}
\hline $\begin{array}{l}\text { Inquiry } \\
\text { level }\end{array}$ & $\begin{array}{l}\text { Inquiry } \\
\text { Questions }\end{array}$ & Description \\
\hline 1 & $\begin{array}{l}\text { Confirmation } \\
\text { Inquiry }\end{array}$ & $\begin{array}{l}\text { The teacher has taught a specific science theme or topic. The teacher develops } \\
\text { questions then and procedures that guide students through an activity where the } \\
\text { results are known. }\end{array}$ \\
\hline 2 & $\begin{array}{l}\text { Structured } \\
\text { Inquiry }\end{array}$ & $\begin{array}{l}\text { The teacher gives initial questions and an outline of the procedure. Students must } \\
\text { formulate an explanation of their findings through the evaluation and data } \\
\text { analysis they collect. }\end{array}$ \\
\hline 3 & Guided Inquiry & $\begin{array}{l}\text { The teacher only provides research questions for students. Students are } \\
\text { responsible for designing and following their own procedures for testing that } \\
\text { question and then communicating their results and findings. }\end{array}$ \\
\hline 4 & $\begin{array}{l}\text { Open/True } \\
\text { Inquiry }\end{array}$ & $\begin{array}{l}\text { Learners formulate their own research questions, design and follow up with } \\
\text { developed procedures, calculated mathematical data, and communicate their } \\
\text { findings and results. }\end{array}$ \\
\hline
\end{tabular}

The Royal Society's Science Policy Center [16] stated that open inquiry is at the core of scientific endeavors and experimental and observational data which are the basis of allowing others to identify errors, support, reject, or correct theories, counting math, and reuse data for further understanding and knowledge and the strong ability of science to make self-correction comes from the openness of supervision and challenges. Zion et al [17] avowed that to facilitate open inquiry, teachers must possess complex teaching skills then make it possible to support and direct learners in creative thinking and to resolve many uncertain situations. Banci and Bell [15] explain that the teacher gives the problem to students to be investigated at the level of guided inquiry, but at the level of open inquiry the problem is found by the students with teacher's direction and guidance so that students can find out for themselves what can be asked and the question finally it leads to new problems that need to be followed up as the next activity. Suryani \& Sudargo [18] stated that open inquiry is the most complex level of learning by giving freedom to students to take the initiative in solving existing problems, including; conduct research activities on the topic through asking questions that have been formulated, determine hypotheses, choose equipment and procedures for activities independently and responsibly with the role of teachers who are not too involved in guiding students.

Conclusion, open inquiry learning is a learning model has the most complex level of scientific inquiry able to give students the opportunity to identify mistakes, submit suggestions, to support or reject according to existing theories and concepts so students can improve their ability to investigate independently in investigations open and students are able to conduct supervision and self-correction. 


\subsection{What is scientific attitude?}

Scientific attitude is the ability to be consistent, objective and rational in problematic situations, these attitudes can contribute to the attitude of students in learning science [19]. Similarly, when John \& Ademoia [20] revealed that someone who has a scientific attitude is not necessarily a scientist but he will think, act and show a general attitude like a scientist where the scientific attitude is the tendency of students to act well or unfavorably in class according to the ethics of science consistently, rationally and objectively.

Students who have a scientific attitude will not receive a theory if it has real evidence because scientific attitude is a way of thinking logically without prejudice [21]. Agree with the statement [22] where the scientific attitude is "scientific spirit" or "scientism" which can create rational prospects so that it will help overcome the problem objectively and logical thinking. A more detailed description of scientific attitudes will be included in Table 2 .

Table 2. Indicators of scientific attitudes

\begin{tabular}{|c|c|c|}
\hline No & Scientific attitude & Indicator \\
\hline 1 & Curiosity & $\begin{array}{l}\text { Actively asking questions about the material being studied } \\
\text { Observe } \\
\text { Look for answers enthusiastically } \\
\text { Find out every step of the activity }\end{array}$ \\
\hline 2 & Honesty & $\begin{array}{l}\text { Write observations down as is. } \\
\text { Do not see the observations of others } \\
\text { Do not combine facts with opinions } \\
\text { Receive observations } \\
\text { No cheating }\end{array}$ \\
\hline 3 & Cooperate & $\begin{array}{l}\text { Appreciate friends' findings } \\
\text { Do not feel arrogant with their own opinions } \\
\text { Willing to listen other people's arguments } \\
\text { Do teamwork in practicum } \\
\text { Willing to change opinions based on strong evidence } \\
\text { Have a discussion every decision making }\end{array}$ \\
\hline 4 & Perseverance & $\begin{array}{l}\text { Appreciate friends' findings } \\
\text { Do not feel arrogant with their own opinions } \\
\text { Willing to listen to other people's arguments } \\
\text { Work with a team in practicum } \\
\text { Willing to change opinions based on strong evidence } \\
\text { Have a discussion every decision making }\end{array}$ \\
\hline 5 & Thorough & $\begin{array}{l}\text { Pay attention to empirical facts } \\
\text { Work carefully in practicum } \\
\text { Delay the decision until enough data is collected } \\
\text { Follow activities based on instructions }\end{array}$ \\
\hline 6 & Critical thinking & $\begin{array}{l}\text { Find as much information as possible } \\
\text { Pay attention to data even if it is small. } \\
\text { Do not immediately accept conclusions without strong evidence } \\
\text { Presenting a different report with other friends } \\
\text { Change opinions in response to facts }\end{array}$ \\
\hline 7 & Responsible & $\begin{array}{l}\text { Dare to defend opinions about the results of practicum } \\
\text { Gather reports and assignments on time } \\
\text { Clean tools, materials, and laboratories after class practice }\end{array}$ \\
\hline
\end{tabular}

During the learning process, students are trained to respect data and think openly to obtain information based on the results of data collection and analysis during practicum. Scientific attitude influences student achievement. If the scientific attitude is better, so the learning achievement more complete. The application of learning models will be implemented well if students have a good scientific attitude. Rohaeti, Prodjosantoso and Irwanto [23] also stated that the learning environment is a determining factor that influences students' scientific attitudes such as rationality, curiosity, open-minded, aversion to superstition, objectivity, intellectual honesty, suspended judgment, critical-mindedness and humility during the learning process.

A scientific attitude can make thinking more open and willing to consider new facts when making judgments, do not make conclusions until all the facts are collected and have enough accurate evidence to make conclusions [24]. Scientific attitudes in learning are often associated with attitudes to science [25]. These two attitudes are interrelated influencing the action. Scientific attitudes in learning science contribute high in the formation of scientific attitudes 
of students, but there are still other factors that contribute. The application of knowledge and abilities/skills based on scientific attitudes makes it possible for students to make decisions and solve problems. Scientific attitude becomes a matter of students that must be considered [26] and improved [27]. Science learning needs to lead to scientific attitude [28].

\subsection{Correlation between Open Inquiry Learning and scientific attitude}

Open inquiry learning is skills-based learning which in the process of inquiry learning activities involved some skills. John \& Ademoia [20] have stated that a scientific attitude is the ability to be consistent, objective and rational in problematic situations, this attitude can contribute to the attitudes of students in studying science. It is the same when Kusumaningrum, Ashadi1 and Indriyanti [29] have revealed that a scientific attitude is the tendency of students to act either good or bad in class according to science ethics consistently, rationally and objectively. Since a long time ago, the role of teachers to develop students 'scientific attitudes, such as providing examples of scientific attitudes, namely enthusiasm for new discoveries, so that there has been a sense of enthusiasm in students for new discoveries, it will be easy to direct students' thinking, with new findings that can change the ideas or opinions they have expressed [30]. Open inquiry learning teaches important skills. The skills involve in open inquiry learning shown in the Table 3.

Table 3. The results of students' scientific attitude

\begin{tabular}{|l|l|}
\hline Author & Indicator of Scientific Attitude \\
\hline Hastuti, Nurohman, and Setianingsih (2018) [27] & Curiosity, respects toward facts, and open mindedness \\
\hline Nath and Thomas (2012) [31] & $\begin{array}{l}\text { Rationality, curiosity, open-mindedness, open- } \\
\text { mindedness, objectivity of intellectual belief, computed } \\
\text { chemical data through a mathematical process, and } \\
\text { suspended judgement }\end{array}$ \\
\hline Mayangsari, Yusrizal and Mustafa (2019) [32] & $\begin{array}{l}\text { Curiosity, respect for data/facts, critical thinking, discovery } \\
\text { and creativity, open minded and team player, } \\
\text { perseverance, computed chemical data through a } \\
\text { mathematical process, and sensitivity to surrounding } \\
\text { environment }\end{array}$ \\
\hline Widowati, Nurohman, and Anjarsari (2017) [8] & $\begin{array}{l}\text { Curiousity, respect towards facts, and care towards } \\
\text { environment. }\end{array}$ \\
\hline Sandika and Fitrihidajati (2018) [7] & $\begin{array}{l}\text { Curiosity, computed chemical data through a } \\
\text { mathematical process, and objectivity }\end{array}$ \\
\hline Putra, Milama, and Saridewi (2017) [33] & $\begin{array}{l}\text { Courius, respect to data, flexible thinking, critical thinking, } \\
\text { and considerate attitude to environment }\end{array}$ \\
\hline Misbah, Dewantara, Hasan, and Annur (2018) [5] & $\begin{array}{l}\text { Curiosity, discovery, critical thinking, computed chemical } \\
\text { data through a mathematical process, and strong } \\
\text { determination }\end{array}$ \\
\hline Lacap (2015) [34] & $\begin{array}{l}\text { Curiosity, open-mindedness, aversion to superstition, } \\
\text { objectivity and rationality }\end{array}$ \\
\hline Ekawati (2017) [35] & $\begin{array}{l}\text { Curiosity, open mind, objective, willingness to postpone } \\
\text { judgments, persistence }\end{array}$ \\
\hline Pitafi and Farooq (2012) [36] & $\begin{array}{l}\text { Curiosity, criticality, rationality, open mind, objective, } \\
\text { willingness to postpone judgments, humility }\end{array}$ \\
\hline
\end{tabular}

Applying open inquiry learning requires students to develop research questions, decide what methods to use, collect and analyze data, and handle ambiguity in their data, and present conclusions, thereby encouraging students to have good scientific attitudes such as curiosity, respect towards facts, and care towards the environment [8]. Learners start to collaborate and group discussions understand the methods they develop and analyze their findings so that it will help develop students' scientific attitudes in group work [7]. Open inquiry learning opens up students' way of thinking, that the learning material being studied can be easily understood by looking and understanding events that they have known before. If this open inquiry learning system is successfully implemented, it will train students' thinking skills to be more improved, so that if students are faced with a variety of complex problems, students will be able to overcome them. Open inquiry as one of the learning models that play an important role in the education system has the potential to improve their thinking abilities and scientific attitudes [8].

Open inquiry-based learning can facilitate the development of learner attitudes. Attitude is the result 
of learning which belongs to the affective domain. Attitude is a judgment or belief system that influences a persons' behavior towards people, objects and processes or events [32]. Related with the opinions of Putra, Milama and Saridewi [33] through inquiry that is able to provide the widest opportunity for students and develop scientific attitudes in students. Inquiry learning provides an opportunity for students to interact between those believed by previous students and new evidence they have obtained to achieve better understanding through process and exploration so as to give rise to students' attitudes to continue to seek explanations and respect the opinions of others, and have an open attitude with new ideas, think critically, honestly, and creatively like the performance done by scientists [5]. Learning activities through inquiry exposes students to concrete experiences so that students learn actively, where they are encouraged to take initiatives in efforts to solve problems, make decisions, and develop research skills and train students into lifelong learning [33].

\subsection{Why is open inquiry learning effective on students' scientific attitude?}

The first reason why open inquiry learning is effective in improving students' scientific attitudes is learning activities. Open inquiry based learning activities stimulate students to use their prior knowledge and skills. Learning activities provide a supportive environment for students to explore and use the skills they have acquired. The activities carried out in chemistry learning determine the attainment of students' attitudes. Open inquiry learning provides learning steps that guide students to carry out activities that involve students in conducting investigations and direct experience with objects. Open inquiry based learning activities support students to have a better understanding of a topic, deeper learning, higher level reading, and increased motivation to learn [37].

The second reason why open inquiry-based learning is effective in improving students 'scientific attitudes is students' skills in inquiry. Students make observations and conclude to stimulate questions. They conduct investigations and research while solving problems and building teamwork to achieve learning goals through various activities that require science process skills [32].

\section{CONCLUSION}

The finding indicated that instruction in open inquiry learning able to give students the opportunity to identify mistakes, submit suggestions, to support or reject according to existing theories and concepts so students can improve their ability to investigate independently in investigations open and students are able to conduct supervision and self-correction so open inquiry model effective to improve students' curiosity, respect to data, critical thinking, open mindedness, discovery and rationality because the open inquiry learning process provides a supportive environment for students to explore prior knowledge, computed chemical data through a mathematical process, and skills in carrying out the steps of inquiry to solve problems through teamwork in chemistry learning.

\section{AUTHORS' CONTRIBUTIONS}

Betzy Rampean carried out literature study, the design of the study and performed the data analysis. Eli Rohaeti carried out the participated in the sequence alignment and drafted the manuscript. Jewish Septriwanto participated in analyze math skills in chemistry. Meilan Lengkong participated in design and coordination and helped to draft the manuscript.

\section{REFERENCES}

[1] National Education Standards Agency, Report of National Education Standards Agency, 2010, Jakarta.

[2] Tika Anggraeni, Sugiyo, and Kustiono, he Difference of Ability to Ask, Scientific Attitude, Motivation Before and After Following Contextual Teaching and Learning Model, Journal of Primary Education, Semarang, 2017, pp. 248-56

DOI: https://doi.org/10.15294/JPE.V6I3.21097

[3] Rini Budiharti and Waras N S, Analysis of Student's Scientific Attitude Behaviour Change Effects Blended Learning Supported By I-Spring Suite 8 Applicatio, J. Phys: Conf. Series, Semarang, 2018 pp. 1-10 DOI: https://doi.org/10.1088/17426596/1022/1/012024

[4] Utibe C. Ataha1 and Augustine E. Ogumogu, An Investigation Of The Scientific Attitude Among Science Students In Senior Secondary Schools In Edo South Senatorial District, Edo State, Journal of Education and Practice, Pakistan, 2013 pp. $12-16$ 
[5] Misbah, Dewi Dewantara, Sayid Muhammad Hasan, and Syubhan Annur, The Development of Student Worksheet by Using Guided Inquiry Learning Model to Train Student's Scientific Attitude, Unnes Science Education Journal, Semarang, 2018, pp. 19-26 DOI: https://doi.org/10.15294/USEJ.V7I1.15799

[6] Baris Ozden and Nilgun Yenice, An Analysis of the Secondary Education Students' Scientific Attitudes, International Journal of Contemporary Educational Research, Taiwan, 2014 pp. 86-97

[7] Bayu Sandika and Herlina Fitrihidajati, Improving Creative Thinking Skills and Scientific Attitude Through Inquiry-Based Learning in Basic Biology Lecture toward Students of Biology Education, Indonesian Journal of Biology Education, Malang, 2018 pp. 23-8

DOI: https://doi.org/10.22219/jpbi.v4i1.5326

[8] Widowati A, Nurohman A and Anjarsari P, Developing Science Learning Material With Authentic Inquiry Learning Approach To Improve Problem Solving And Scientific Attitude, Jurnal Pendidikan IPA Indonesia, Semarang, 2017, pp.. $32 \quad-40$ DOI:https://doi.org/10.15294/ipii.v6i1.4851

[9] R S Coffman, Coffman's Method of Conduit Bending, Canada: Delmar Cengage Learning, 2009, pp. 51-4

[10] Bell R L, Smetana and I Binns, National Science Teacher Association, 2005 pp. 30 - 33

[11] Ela Ayse Koksal and Giray Berberoglu, The Effect of Guided-Inquiry Instruction on 6th Grade Turkish Students' Achievement, Science Process Skills, and Attitudes toward Science, International Journal of Science Education, United Kingdom, 2014, pp. 66-78 DOI: http://dx.doi.org/10.1080/09500693.2012.72194 $\underline{2}$

[12] Mataka L M and Kowalske M G, The Influence of PBL on Students' Self-Efficacy Beliefs in Chemistry Chemistry Education Research and Practice, Greece, 2015, pp. 929-38 DOI: http://dx.doi.org/10.1039/c5rp00099h

[13] $\mathrm{T}$ Tatsuoka, $\mathrm{K}$ Shigedomi and $\mathrm{N}$ Koga, Using A Laboratory Inquiry Withi High School Students to Determine the Reaction Stoichiometry of Neutralization by A Thermochemical Approach, Joumnal of Chemical Education, United States, 2015, pp. 1526-3150

DOI: http://dx.doi.org/10.1021/ed500947t

[14] S Supasorn, Grade 12 Students' Conceptual Understanding and Mental Models of Galvanic Cells Before and After Learning by Using Small-Scale Experiments in Conjunction With A Model Kit, Chemistry Education Research and
Practice, Greece, 2015, pp. 393-407. DOI: http://dx.doi.org/10.1039/c4rp00247d

[15] H Banchi and R Bell, The Many Levels of Inquiry, National Science Association, United States, 2008, pp. 26-29. https://www.jstor.org/stable/43174976

[16] The Royal Society Science Policy Centre, Science As An Open Enterprise, London: The Royal Society, 2012, pp. 310-319

[17] M Zion, I Schanin and E R Shmueli, Teachers' Performances During A Practical Dynamic Open Inquiry Process, Teachers and Teaching: Theory and Practice, United Kingdom, 2013 pp. 695-716. DOI: https://doi.org/10.1080/13540602.2013.827457

[18] Dwi Indah Suryani, Fransisca Sudargo, Pengaruh Model Pembelajaran Open Inquiry Dan Guided Inquiry Terhadap Sikap Ilmiah Siswa SMP pada Tema Suhu dan Perubahan, Jakarta, Edusains, pp. 1- 5. DOI: https://doi.org/10.15408/es.v7i2.1628

[19] R Ergul, Y Simsekli, S Calis, Z Ozdilek, S Gocmencelebi and $M$ Sanli, The Effect of Inquiry-Based Science Teaching on Elementary School Students' Science Process Skills and Science Attitudes, Bulgarian Journal of Science and Education Policy, Bulgaria, 2011, pp. 48- 68

[20] Kayode John Olasehinde and Rafiu Ademola Olatoye, Scientific Attitude, Attitude to Science and Science Achievement of Senior Secondary School Students in Katsina State, Nigeria, Journal of educational and society research MCSER publishing Rome-Italy, 2014 pp. 445452 http://doi.org/10.5901/jesr.2014.v4n1p445

[21] S Chandrasekaran, Developing Scientific Attitude, Critical Thinking and Creative Intelligence of Higher Secondary School Biology Students by Applying Synectics Techniques, International Journal of Humanities and social science invention, United States, 2014, pp. 1-8

[22] Gurpreet Kaur, Scientific Attitude In Relation To Critical Thinking among Teachers, Educationia Confab Journal, Mempis, 2013, pp. 24-30

[23] Eli Rohaeti, Anti Kolonial Prodjosantoso and Irwanto, Research-Oriented Collaborative Inquiry Learning Model: Improving Students' Scientific Attitudes In General Chemistry, Journal of Baltic Science Education, Lithuania, 2020, pp. 108-120. DOI: https://doi.org/10.33225/jbse/20.19.108

[24] A A Carin and R B Sund, Teaching Modern Science $7^{\text {th }}$ edition, Merril Printice Hall: New Jersey, 1980, pp. 472-479. 
[25] Bundu Patta, Penilaian Keterampilan Proses dan Sikap Ilmiah, Jakarta: Depdiknas, 2006, pp 32-36.

[26] M G Devi and N Aznam, The Effect of Science-Technology-Society (STS) Model on Scientific Literacy And Scientific Attitude of Students on The Subject of Buffer, J. Phys: Conf. Series, Yogyakarta, 2019, pp. 1-6. DOI: http://doi.org/10.1088/17426596/1156/1/012027.

[27] P W Hastuti, S Nurohman and W Setianingsih, The Development of Science Worksheet Based on Inquiry Science Issues to Improve Critical Thinking and Scientific Attitude, J. Phys: Conf. Series, Yogyakarta, 2018, pp. 1-7. DOI: http://doi.org/10.1088/17426596/1097/1/012004

[28] Nurul Hilalliati, Jumadi, Insih Wilujeng, and Heru Kuswanto, J. Phys: Conf. Series, Yogyakarta, 2019, pp. 1-7. DOI: http://doi.org/10.1088/17426596/1233/1/012050

[29] I A Kusumaningrum, A Ashadil dan N Y Indriyanti, Scientific Approach and Inquiry Learning Model in the Topic of Buffer Solution: A Content Analysis, J. Phys: Conf. Series, Yogyakarta, 2017, pp. 1-6. DOI: http://doi.org/10.1088/1742-6596/895/1/01204

[30] J P Kenny, P Quin, and N Taylor, The School Science Attitude Survey: A New Instrument for Measuring Attitudes towards School Science, International Journal of Research \& Method in Education, United Kingdom, 2016, pp. 422-445 http://dx.doi.org/10.1080/1743727X.2016.11600 46

[31] Sreetanuka Nath and Sybil Thoma, Enhancing Science Process Skills and Scientific Attitude and Analysing their Interactions: An Intervention through Inquiry Learning Approach, International Journal of Scientific Research Education, Paris, 2012 pp. 37-42

[32] F Mayangsari, Yusrizal and Mustafa, Application of Guided Inquiry Learning Model to Improve Students' Scientific Attitudes and Learning Outcomes, J. Phys: Conf. Series, Aceh, 2020, pp. 1-6. DOI: http://doi.org/10.1088/17426596/1460/1/012138

[33] Gita Dynamika Putra, Burhanudin Milama, Nanda Saridewi, Scientific Attitude Profile of Student Through Guided Inquiry by Experiment Method Advances in Social Science, Education and Humanities Research Journal, Paris, 2017, pp. 191-195. DOI: http://doi.org/10.2991/icems17.2018 .37

[34] Marjorie P Lacap, The Scientific Attitudes of Students Major In Science in the New Teacher
Education Curriculum, Asia Pacific Journal of Multidisciplinary Research, Philippines, 2015, pp. 7-15

[35] Elvin Yusliana Ekawati, A Model of Scientific Attitudes Assessment by Observation in Physics Learning Based Scientific Approach: Case Study of Dynamic Fluid Topic in High School, J. Phys: Conf. Series, Semarang, 2017 pp. $1-9$. DOI: https://doi.org/10.1088/1742-6596/795/1/012056

[36] Amjad Islam Pitafi and Muhammad Faroog, Measurement of Scientific Attitude of Secondary School Students in Pakistan, Academic Research International, United Kingdom, 2012, pp. 379392

[37] Eskaria Sirait, Motlan and Retno Dwi Susanti, The Effect of Inquiry Training Learning Method with the Help of Multimedia and Scientific Attitudes to The Students Science Ability, Journal of Research \& Method in Education, United Kingdom, 2017, pp. 46-50. DOI: http://doi.org/10.9790/7388-0706024650 